\title{
Global Warming and Water Resources Variability in the Maritime Region of Togo (West Africa)
}

\author{
Kwami Coco Dzidula Agbewornu ${ }^{1}$ \\ ${ }^{1}$ School of Urban Construction and Environmental Engineering, Chongqing University, China \\ Correspondence: Kwami Coco Dzidula Agbewornu, School of Urban Construction and Environmental \\ Engineering, Chongqing University, 400045, China. E-mail: olive.coco55@yahoo.com
}

Received: November 8, 2018

Accepted: November 19, 2018

Online Published: November 30, 2018

doi:10.5539/enrr.v8n4p49

URL: https://doi.org/10.5539/enrr.v8n4p49

\begin{abstract}
One of the most important climatic phenomena of our planet on the threshold of this third millennium is undoubtedly that of global warming. This phenomenon, whose impact on the global environment is disastrous, has been attracting the attention of the international community since the end of the last century. Global warming can be observed on a global scale, but with regional and local signatures. In Togo, the Maritime region which houses the bulk of industrial activities $(90 \%)$ and densely populated ( $40 \%$ of the national population), would be more exposed to the effects of global warming than all the other regions of the country. The current study uses meteorological and hydrological data to calculate statistical indexes which show the evolution of temperatures and water resources variability. The aim is to detect the signs of global warming and the variability of water resources in order to envisage better adaptation strategies. The results of the analysis of climate data for a long enough period (30 to 50 years) demonstrated a change on rain distribution after 1960 which is prejudicial to rainfall agriculture practiced by about $90 \%$ of Togolese crop growers, and an augmentation of the average temperature about 2.2 degree celsius for Lomé and 1.7 degree celsius for Tabligbo.
\end{abstract}

Keywords: Global warming, water resources variability, Vulnerability, Maritime region, Togo, West Africa

\section{Introduction}

While the climate has always varied over time, in recent years, there has been a series of adventures that put climate research at the forefront of the news. These elements relating to water are natural disasters such as floods, droughts(Peeraer et al., 2015; Zhao, Xu, Zhang, \& Li, 2016), the scarcity of fresh water due to the intrusion of saline water. According to the Intergovernmental Panel on Climate Change (IPCC) fifth Assessment Report (ARS), the global surface mean temperature has risen by $0.85 \mathrm{C}$ during the $1880-2012$ period. Greenhouse gases contributed to the global mean surface warming whiting the range of $0.5 \mathrm{C}-1.3 \mathrm{C}$ over the 1951-2010 period with increased risk of drought and increase intensity of storms (United Nations Framework Convention on Climate Change (UNFCCC), 2011). Collins, et al. (2011) reported a significant increasing trend in temperature for all Africa. West Africa is facing an increasing number of natural disasters (Intergovernmental Panel on Climate Change (IPCC), 2013), the frequency and intensity of which will increase further as a result of climate warming (Defrance, et al., 2017). West Africa has experienced an increase in floods during recent years. In 2007, 2.6 million people were affected, causing several losses of life (Wade, Faye, Dieng, Kaba, \& Kane, 2009). To this it is necessary to add a strong coastal erosion on the whole coasting (Intergovernmental Oceanographic Commission (IOC), 2010). At the same time, soil erosion, forest resource degradation and desertification threaten food security (Ozer, Hountondji, Niang, Karimoune, Manzo, \& Salmon, 2010; Stringer, Akhtar, Marques, Amiraslami, Quatrini, \& Abraham, 2011). In Togo and more particularly in the Maritime region, the climate situation has been disturbed for several years by repeated anomalies. According to the country's NAPA (National Adaptation Program of Action of Togo), the sectors that will be most affected by the global warming are agriculture, health, fisheries, water and coastal resources (United Nations Development Programme (UNDP) \& Ministère de l'Environnement et des Ressources Forestières Togo, 2009). Between 1925 and 1992, Togo endured 60 floods events that caused major damage to infrastructures, as well as significant environmental, social and economic damage (Sodogas \& Gomado, 2006). The successive flooding has leeched essential nutrients from top soils, accelerated erosion and degraded the quality of the arable land (IPCC, 2013). The most recent severe flooding occurred in 2007 (Djaman \& Ganyo, 2015) and 2010. In 2007, over 127.000 people were affected, 13764 displaced and dozens killed. The 2010 flooding 
affected 83000 people and resulted in over 38 million USD in damage and losses (Kodjovi, 2011). During both flood events, food security plummeted as prices skyrocketed and inflation rate rose. Consequently, many rural Togolese faced limited opportunities to engage in agricultural and other economic activities. Governance deficiencies and a lack of appropriate disaster preparedness plans have severely hampered the country's ability to respond to these hazards (Global Facility for Disaster Reduction and Recovery (GFDRR), 2011). Agriculture is the major source of livelihood for the majority of West Africans (60\% of the labor force) (Jalloh, Nelson, Thomas, Zougmore, \& Roy-Macauley, 2013). In this region where natural resources form the basis of livelihoods and food security, the economies of this region are particularly vulnerable to climate change since the populations are highly dependent on rain-fed agriculture. Many studies have revealed a drastic decrease in precipitation in Africa, (Hubert, Carbonnel, \& Chaouche, 1989; Vyve, 2006) and Togo, is experiencing the same problem since 1970 (Klassou, 1996; Badameli, 1996;1998; Adewi, Badameli, \& Dubreuil, 2010). Sogbedji (1999) found that the decrease in seasonal rainfall amounts represents a serious threat to maize growth during the second growing season. The West African population has grown from 86 million in 1961 to 340 million in 2014 and is expected to reach 800 million by 2050 (Food and Agriculture Organization of the United Nations (FAO), 2017). Gadédjisso (2015) evaluated the farmers' perceptions and the variability of rainfall in Maritime region and indicated that farmers perceived high increased of temperature and decrease of rainfall. Local populations need to be informed of current and future environmental changes in order to accompany them since most of the environmental changes in Africa are related to rainfall (Nicholson, 2011; Zheng, Reid, \& Craing, 1997). We are aware that the vulnerability of water resources due to global warming is at the root of many serious socioeconomic crises around the world. Among these we will mention the decline in food production resulting in famine, the energy crisis resulting in a slowdown in economic activities and especially the appearance of many diseases related to water scarcity.

\section{Material and Methods}

\subsection{Site Description: Location of the Study Area}

Togo is a small West African country with estimated population of about 7.178.000 inhabitants (National Institute of Statistics and Economic and Demographic Studies (INSEED-TOGO), 2015). The Maritime Region which constitutes the field of experimentation of our study is located in the southern part of Togo. With a relatively small surface area (6600 square kilometers) or $11.66 \%$ of the country's area, it extends from $6^{\circ} 10$ 'to $6^{\circ} 60^{\prime}$ north latitude, and lies between the meridians $1^{\circ} 25^{\prime}$ West and $1^{\circ} 50$ 'East of longitude. Limited to the north by the Plateaux region, to the south by the Atlantic Ocean, the Maritime Region marks in the West and East, the national limits respectively with Ghana and Benin.

\subsection{The Climate Anomaly of Southern Togo}

The climate anomaly of southern Togo has a strong impact on the Maritime region. Indeed, although located at almost equatorial latitude, southern Togo has a dry climate. The water slices recorded in all the stations hardly exceed $1000 \mathrm{~mm}$ whereas they are definitely higher than $2000 \mathrm{~mm}$ in Lagos and Abidjan yet located at almost the same latitude. The average temperature is 27 degree Celsius.

\subsection{Data Collection and Processing}

It seemed to us necessary first of all to collect the activity data and then to subject them to a treatment likely to give us the expected results. This operation involved collecting meteorological data, and hydrology data. Meteorological data include: average monthly temperatures (from 1977 to 2017) over a period of 40 years, then monthly precipitation over the same period. Apart from that, the average monthly rainfall over two periods of time was studied: the period of 1935 to 1960 and the period of 1961 to 1985 . Fifteen rain stations were selected after control, but the detailed study focus on four main positions that are Lomé, Tabligbo, Aklakou, Tsevie. The data from all stations come mostly from the national meteorology and the Agency for Aerial Navigation Safety in Africa (ASECNA). The data on water resources were provided to us by the Ministry of Water and Water Resources, the Directorate of Water Resources and the TdE (la Togolaise des Eaux). The annual rainfall and temperature values were computed for each station from the monthly amount using equation (a) and (b):

$$
\begin{aligned}
& A R=1 / 12 \sum_{i=1}^{12} \mathrm{Ri} \\
& A T=1 / 12 \sum_{i=1}^{12} \mathrm{Ti}
\end{aligned}
$$

Where $\mathrm{R}$ is the monthly rainfall amount at each station, $\mathrm{T}$ is the monthly temperature amount for each station, $\mathrm{i}$ is the month of the year, and AR and AT respectively the annual rainfall, and the annual temperature amount for each station. For the analysis of hydro climatic parameters, we have calculated annual averages rainfall and the Nicholson index, to highlight rainfall. The Nicholson index study plays a very important role in determining the 
seasonal variations. Nicholson (1988) cited by Paturel et.al (1997) have defined an index which, calculated each year on the studied period, expressed by:

$$
S I=\frac{\mathrm{X}-\mathrm{Xi}}{\sigma}
$$

$\mathrm{X}$ i: Rainfall height of year i (in mm), X: Average rainfall over the study period (in mm), $\sigma$ : Standard deviation of the rainfall height over the study period. It determines a reduced centered variable Lamb (1982) cited by Hubert, et al. (1998). The average Inter annual series corresponds to the null index (0) called normal. A normal period is a period during which an identical fluctuation is observed on both sides of the x-axis. In this case, the annual average is approximately equal to the average of the total rainfall. During the wet period, the annual average is greater than the average of the total rainfall. Finally, the dry period corresponds to a period where the annual average is less than the average total rainfall. Linear regression also was applied to show the evolution of temperatures in the region.

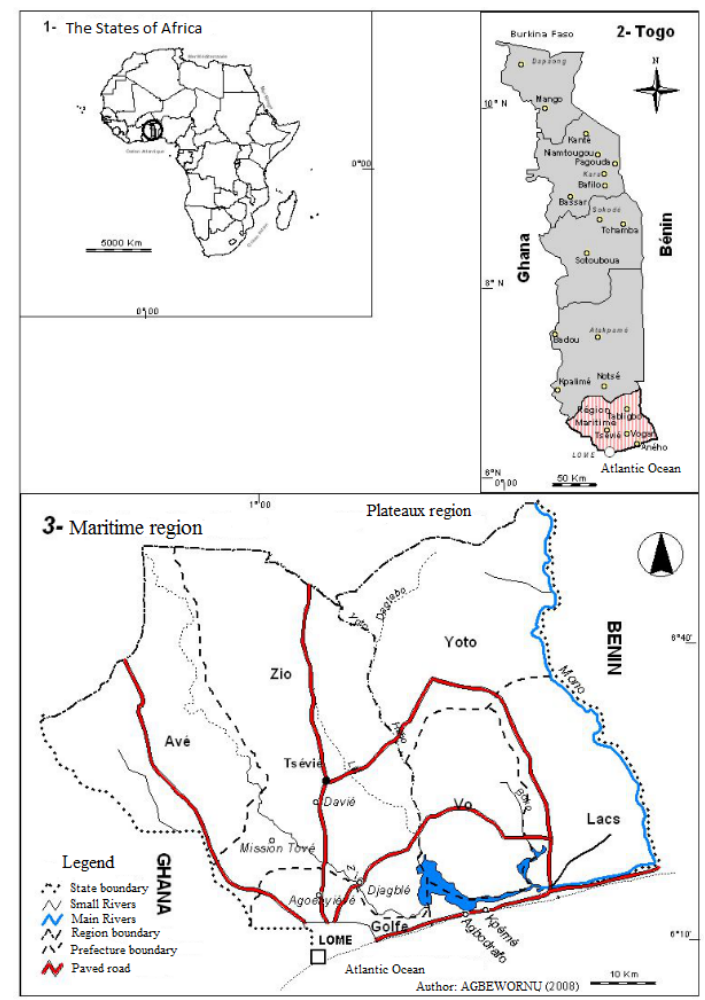

Figure 1. Location of the study area

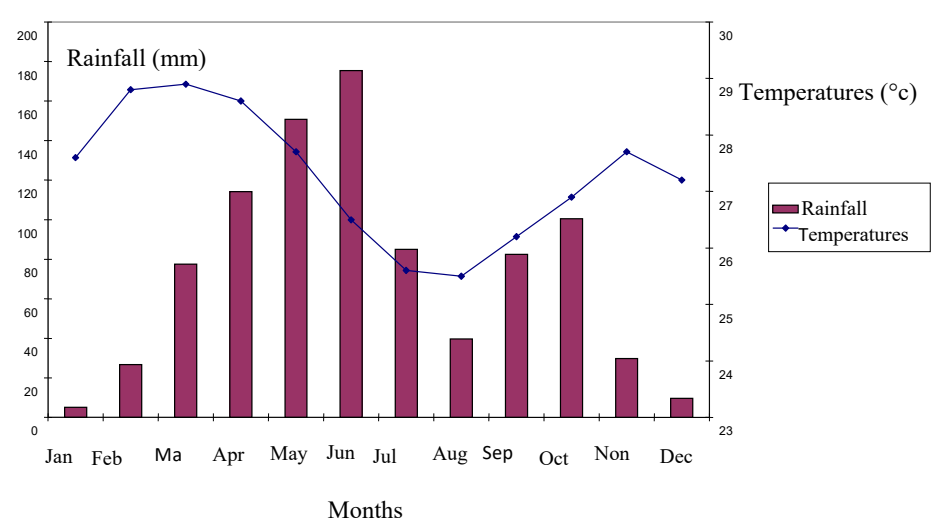

Figure 2. Ombrothermic diagram for Maritime region: Monthly average rainfall and temperatures data from 1977 to 2017 


\section{Results and Discussion}

\subsection{Variability of Water Resources}

Water resources are characterized by temporal and spatial variability in the Maritime Region. This variability is influenced by certain climatic parameters such as temperature, evapotranspiration and air humidity, but for this study we will focus mainly on the temperature.

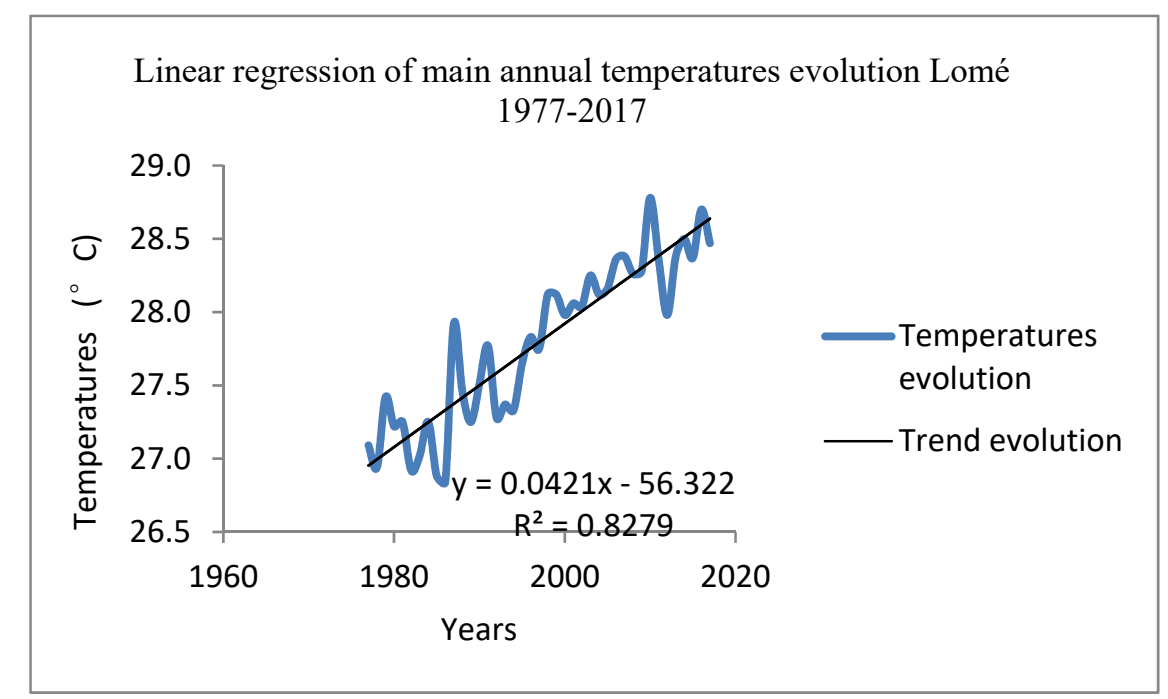

Figure 3. Linear regression of main annual temperatures evolution (Lomé 1977-2017)

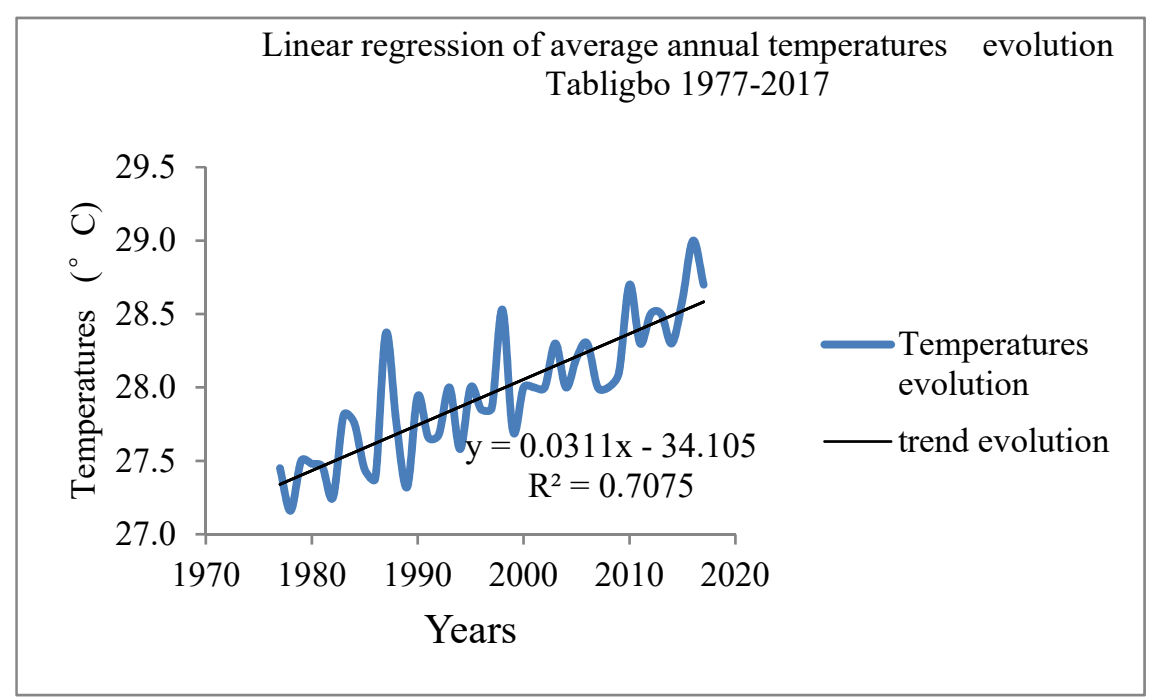

Figure 4. Linear regression of average annual temperatures evolution (Tabligbo 1977-2017)

The evolution of the mean temperature is important as shown in the figures 3 and 4 from 1977 to 2017, in the Maritime Region. The mean temperature rose by $2.2 \mathrm{C}$ at Lome and $1.7 \mathrm{C}$ at Tabligbo. The warmest years started from 2000 in all the locations. Our results confirm the finding of Gadédjisso (2015) who indicated that 95\% of farmers perceived an increase of temperature in the Maritime region from 1961 to 2013. Similar results were also found by Odjugo (2010) and Oguntunde, Abiodun \& Gunnar (2012) who reported that spatial and temporal variations in temperatures were noticed in Nigeria where air temperature has been on the increase gradually since 1901. The mean temperature is an important climate variable that has direct effect on agriculture and ecosystem (Adoussi \& Edjame, 2000). In Togo the temperature increasing from 2000 is not surprising but it only proves that global warming can be revealed even at local scales. The findings of this study are in agreement with IPCC prediction which started from 2007 that, the Earth could warm by $3 \mathrm{C}$ this century. Even with a 
temperature rises of $1 \mathrm{C}-2.5 \mathrm{C}$, the IPCC predicted serious effects including reduced crop yields in tropical areas leading to increasing risk of hunger, spread of climate sensitive diseases such as malaria (IPCC, 2013).

\subsection{Spatio-Temporal Variability of Precipitation:}

Precipitation is erratic and varies from year to year.
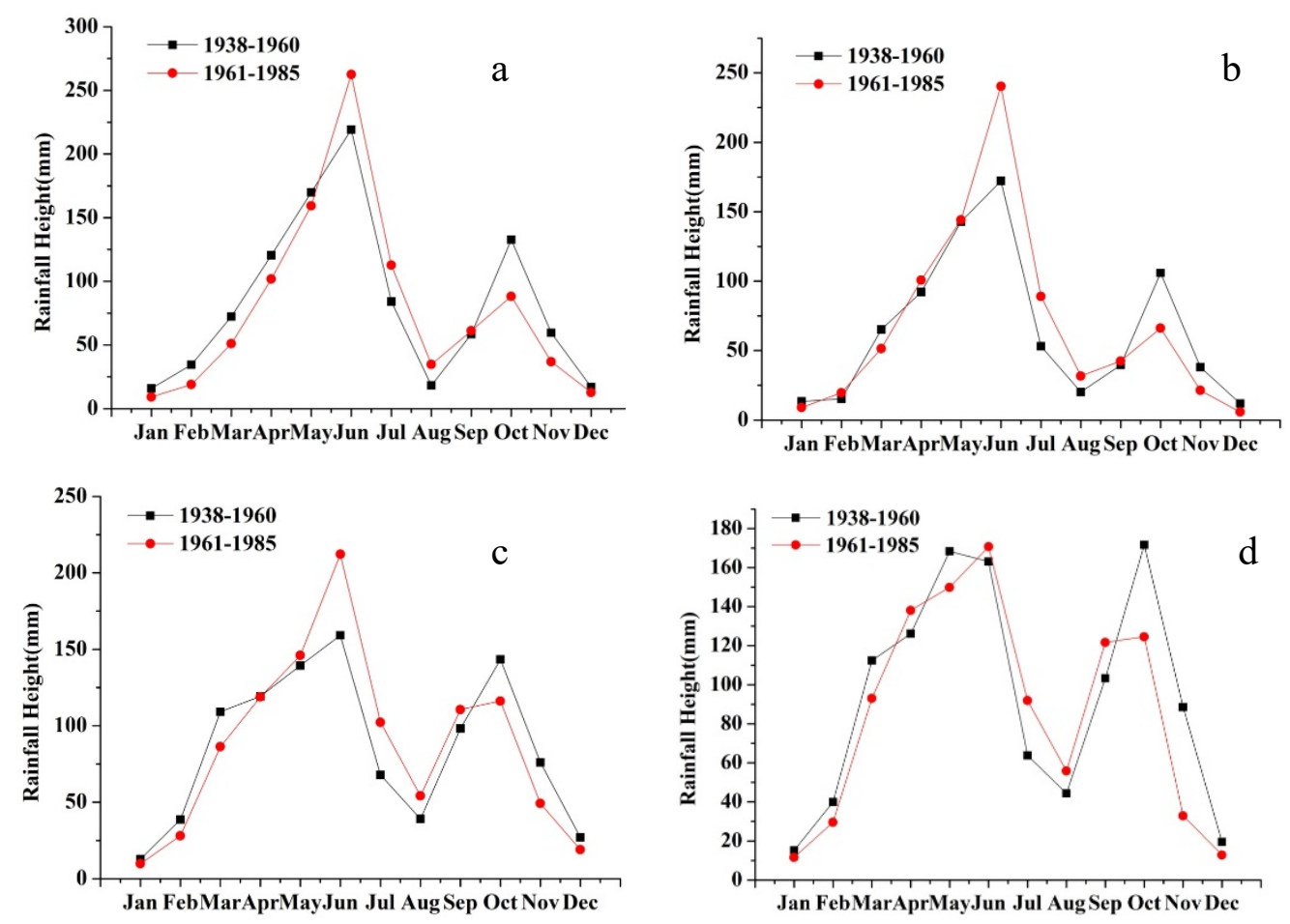

Figure 5. Rainfall evolution at Aklakou (a), Lomé (b), Tsevie (c) and Tabligbo (d)

We find two important phenomena by comparing the period of 1934-1960 to the period 1961-1985, as shows the figure 5: a clear increase in rainfall in the high season (March-July) since 1961 and a clear decrease in rainfall in the short season (September-December) since 1961. Since the total annual rainfall has not changed a lot, it is because the main climate change that has taken place throughout the region is characterized by a report on the high season rains to the short season. It is mainly related to a rain report of the months from October to November, on the months of June to August.

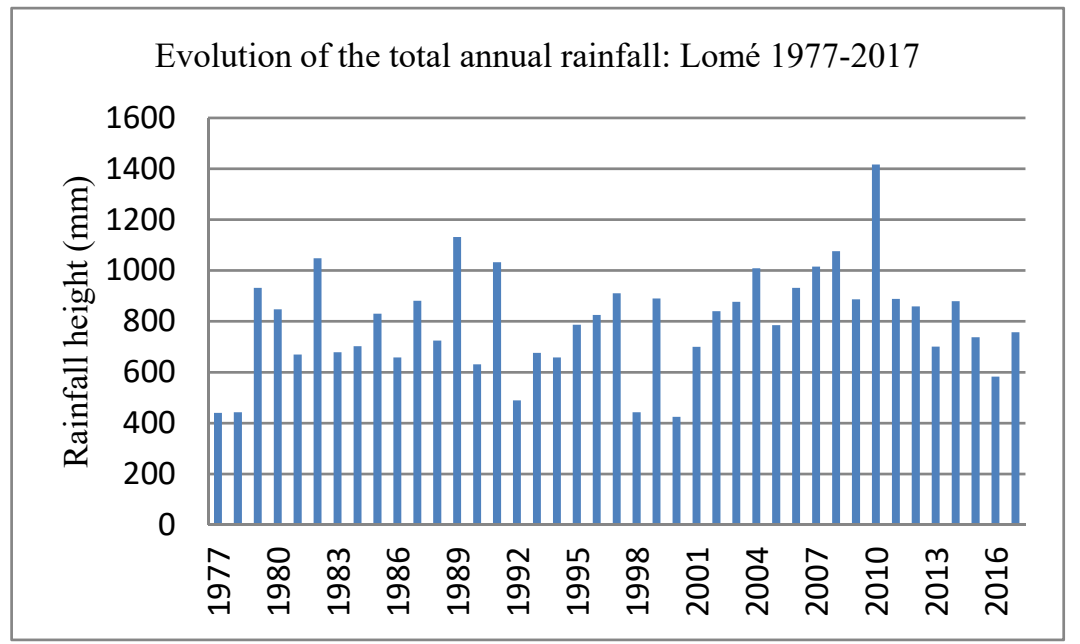

Figure 6. Evolution of total annual rainfall: Lomé 1977-2017 


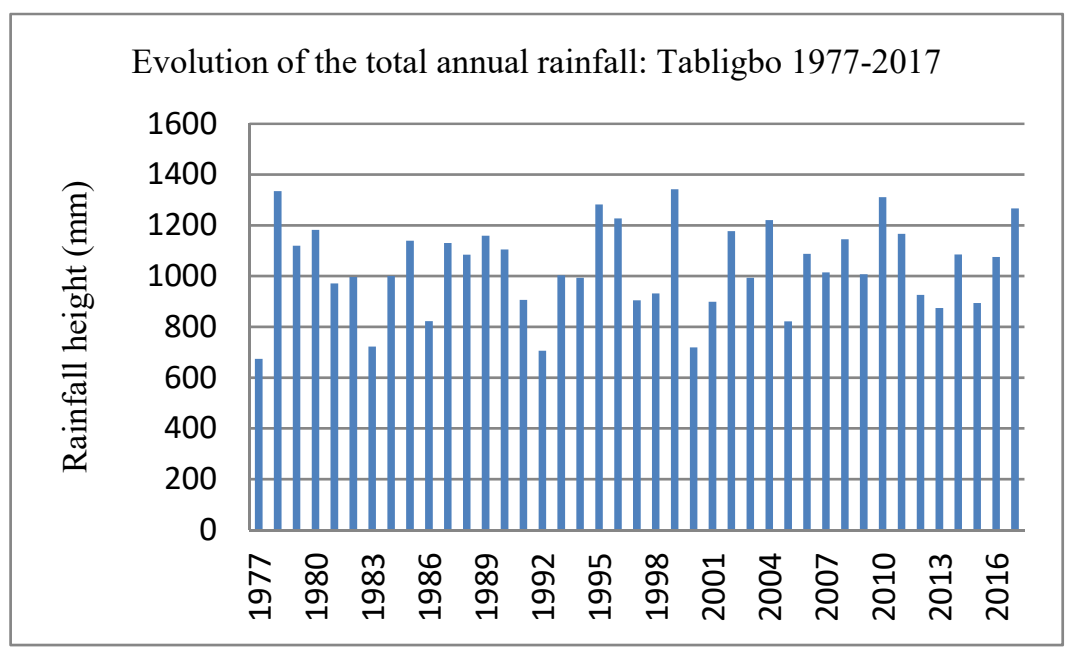

Figure 7. Evolution of the total annual rainfall: Tabligbo 1977-2017

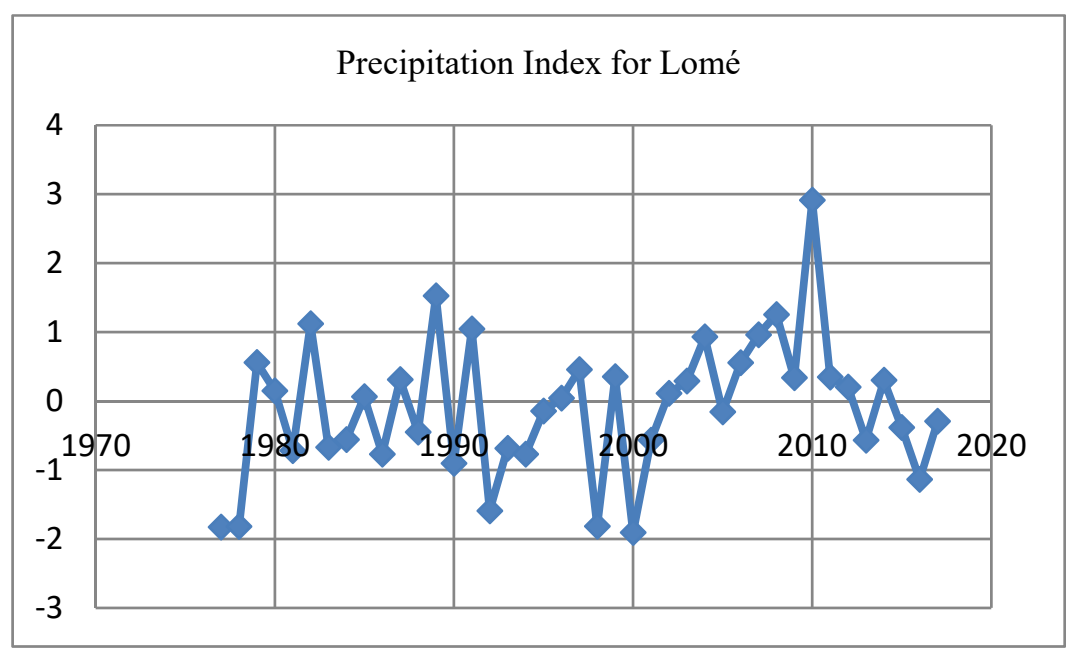

Figure 8. Precipitation Index for Lomé

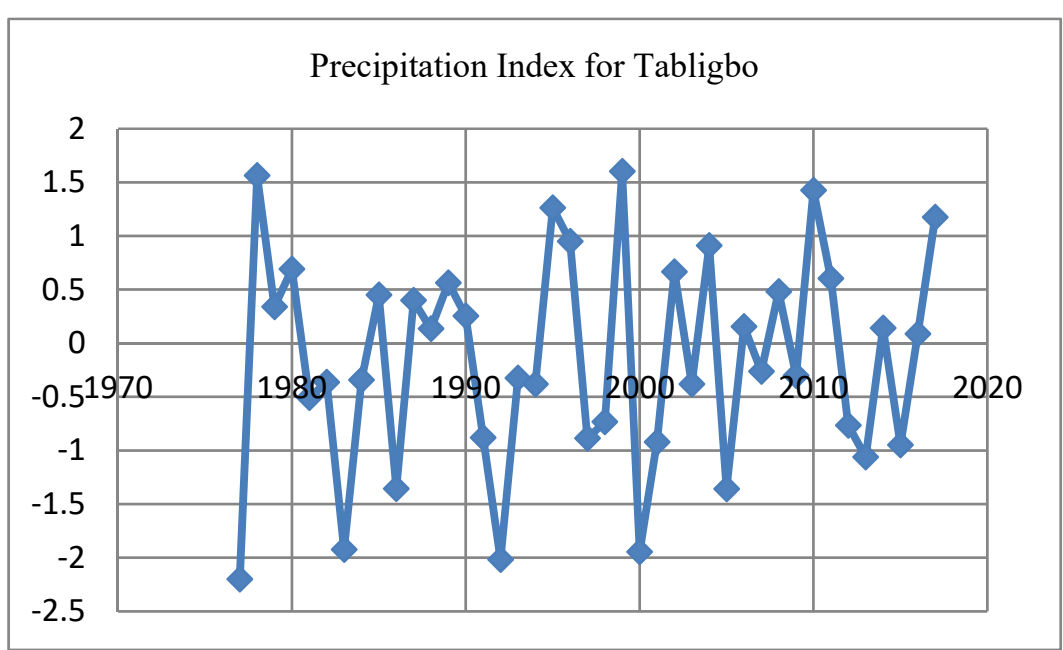

Figure 9. Precipitation Index for Tabligbo

Figure 6 shows the annual total rainfall evolution at Lomé from 1977 to 2017. The rainiest years in Lomé were the years 1989 and 2010 with $1131.3 \mathrm{~mm}$ of rain distributed over 91 days and $1416 \mathrm{~mm}$ of rain spread over 121 
days respectively. Figure 8 also shows sustained dry periods. For example, the severely dry period in 1977 lasted for one year and went up again in 1978. Figure 7 shows the annual total rainfall evolution at Tabligbo from 1977 to 2017. The rainiest years in Tabligbo were the years 1999 and 2010 with $1341.5 \mathrm{~mm}$ of rain distributed over 111 days and $1310.4 \mathrm{~mm}$ of rain spread over 106 days respectively. Figure 9 also shows sustained dry periods. For example, the severely dry period in 1977 lasted for one year. 1983 and 1992 also were extremely dry. In general wet tendency dominates slightly in Lomé and Tabligbo as shown in the rainfall index for those two stations represented by figure 8 and 9. Maritime region's rainfall stations (Lomé, Aneho, Akoumape, Aklakou, Attitogon, Afagna, Tabligbo, Tsevie, Agbelouve ) have the highest rainfall variability as shown in Table 1.

Table 1. Rainfall station annual rainfall height and rainfall variability

\begin{tabular}{|c|c|c|c|}
\hline Rainfall stations & Mean $(\mathrm{mm})$ & Rainfall variability $(\mathrm{mm})$ & Variability $\%$ \\
\hline Lomé & 823 & -334 & -40.574 \\
\hline Aneho & 969 & -297 & -30.702 \\
\hline Akoumape & 857 & -236 & -27.55 \\
\hline Aklakou & 881 & -442 & -50.174 \\
\hline Attitogon & 907 & -190 & -20.958 \\
\hline Afagna & 967 & -518 & -53.546 \\
\hline Tabligbo & 1028 & -82 & -7.996 \\
\hline Tsevie & 1039 & -89 & -8.548 \\
\hline Agbelouve & 1055 & -302 & -28.678 \\
\hline Kpalime-Tove & 1428 & -90 & -6.312 \\
\hline Kouma-Konda & 1714 & -233 & -13.602 \\
\hline Ountivou & 854 & 144 & 16.919 \\
\hline Amou-Oblo & 1441 & -110 & -7.652 \\
\hline Badou-Tomegbe & 1469 & -98 & -6.685 \\
\hline Atakpame & 1335 & -122 & -9.106 \\
\hline Anie-Mono & 1129 & 89 & 7.924 \\
\hline Blitta & 1201 & -406 & -33.846 \\
\hline Sotouboua & 1290 & 8 & 0.65 \\
\hline Tchamba & 1235 & -148 & -11.987 \\
\hline Sokode & 1349 & -271 & -20.061 \\
\hline Guerin-kouka & 1192 & -46 & -3.859 \\
\hline Kpewa-Aledjo & 1490 & -151 & -10.116 \\
\hline Kara & 1321 & 33 & 2.502 \\
\hline Pagouda & 1286 & -192 & -14.935 \\
\hline Niamtougou & 1408 & -170 & -12.084 \\
\hline Kante & 1221 & 11 & 0.911 \\
\hline Mango & 1069 & -80 & -7.513 \\
\hline Takpamba & 1074 & 132 & 12.303 \\
\hline Borgou & 964 & -61 & -6.336 \\
\hline Dapaon & 1025 & -26 & -2.554 \\
\hline
\end{tabular}

\subsection{Variability of Surface Waters}

Maritime region has three main river systems which are Zio, Haho and Mono and two lagoon systems (Klassou, 1996).

3.3.1 Hydrological regime of Zio and Haho

a) Seasonal variations:

Seasonal variations in flow over the Zio and Haho watersheds correspond to the sub-equatorial regime. This regime is characterized by a slight doubling of the high water season corresponding to the two rainy seasons of the studied sector. The two periods of high water are intercalated by two others of low water with unequal sizes. 


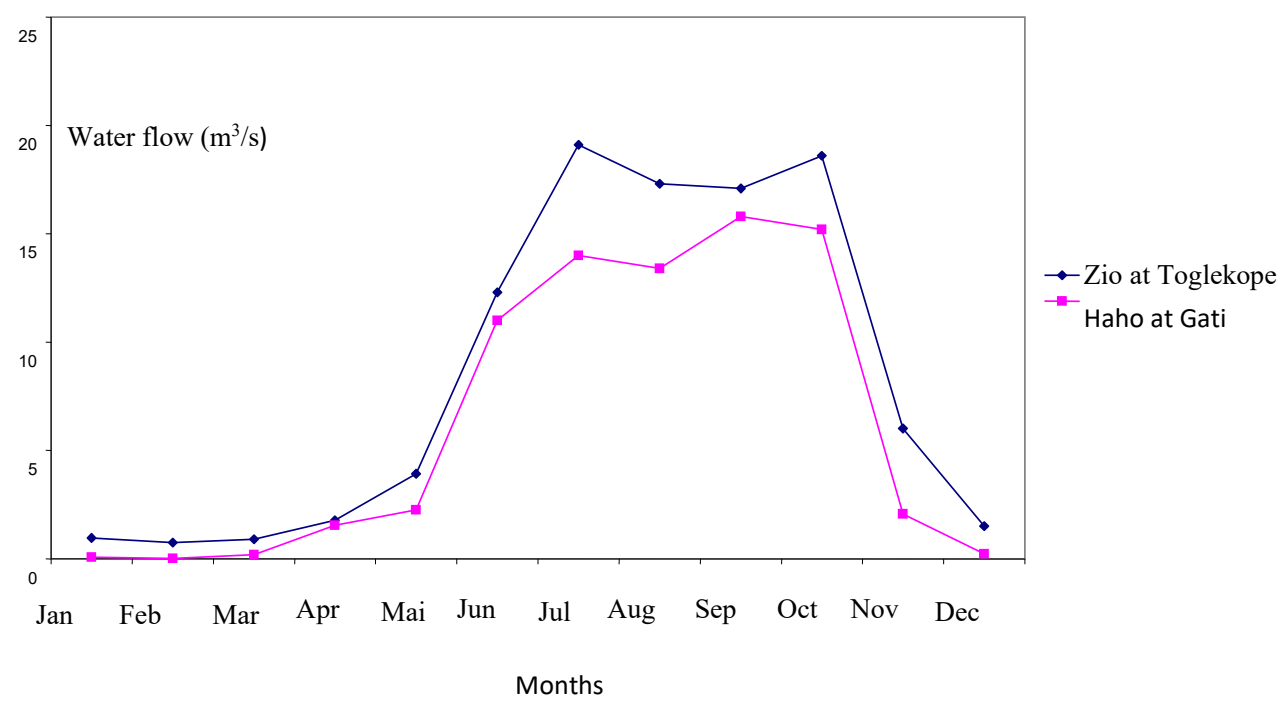

Figure 10. Seasonal variation in Zio and Haho water flow 2016

An analysis of Figure 10 with the graph of mean monthly flows from Zio at Togblekopé and from Haho at Gati makes it possible to locate and understand the different hydrological events. We can already qualify the two extremes respectively by periods of flood and periods of low water.

\section{The high water season}

It is spread over about five months (from mid-July to mid-November) and has two maxima. The first maximum appears in mid-July while the second in mid-September or mid-October. A confrontation of high water seasons and large and small rainy seasons reveals a certain lag of about a month. If the maximum rainfall is reached in June, the first maximum flood occurs in mid-July. This discrepancy is explained by the behavior of the substratum as well as the soil of the watersheds, as factors intervening in the flow of water. In fact, a good part of the rains of the high season are absorbed by the lands that until then were completely dried out by the long dry season which tends to have effects over a period of 4 to 6 months depending on the year (mid-November to midMarch). Drying of the soil causes a delay in the concentration and the appearance of flows in the two rivers, which are not very important. However, the second maximum of the hydrological regime of mid-September or mid-October corresponds textually to the short rainy season. The absence of an offset at this level could be explained by the fact that the state of greater saturation of the soil decreases its infiltration capacity, thereby promoting the superficial runoff which is found very quickly in the bed of said stream.

The low water season

It is remarkable for its long duration, often more than 6 months (December to May), the low water period, which is perfectly similar to the seasonal climatic regime of the environment. Given that the studied area is subjected to a seasonal sub-equatorial rainfall regime (dates of appearance and duration of seasons), this results in a very great inter-annual variability of the period and the duration of the flows.

(b) Inter-annual irregularities in the flow of watercourses.

The Zio and the Haho have a very strong inter-annual variability in the evolution of the regime of these rivers, if we know that they are tributary and at the same time constitute an image of the rhythm of the precipitations.

The curves of the evolution of annual modules and precipitation (Figure 11 and 12) better demonstrate this evolution of the regime over time. They are in the form of sinusoidal curves, thus reflecting the non-permanent flow character of Zio and Haho. Nevertheless, special attention in monitoring these flow curves reveals that some years have been very favorable to flow while others are sources of total indigence. 
Evolution of annual water flow and annual average rainfall over the catchment: Zio at Kpedi (1962-1987)

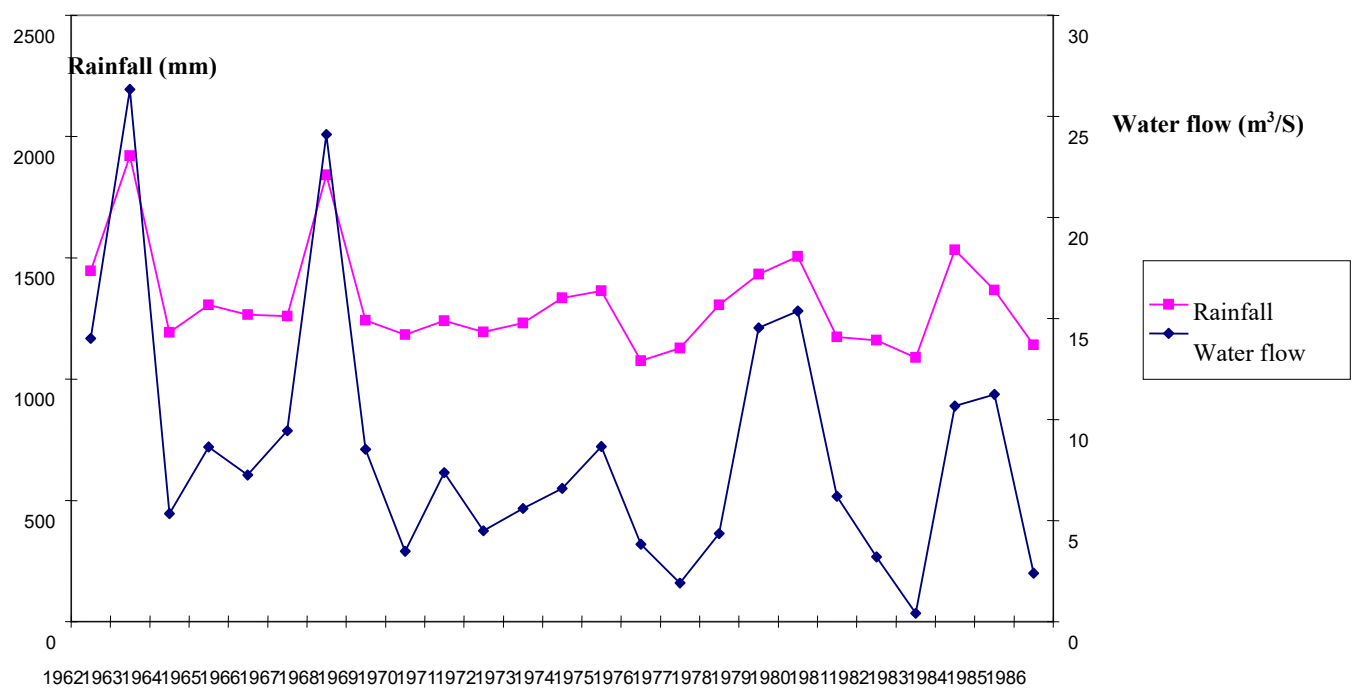

Years

Figure 11. Evolution of annual water flow and annual average rainfall over the catchment: Zio at Kpedi

(1962-1987)

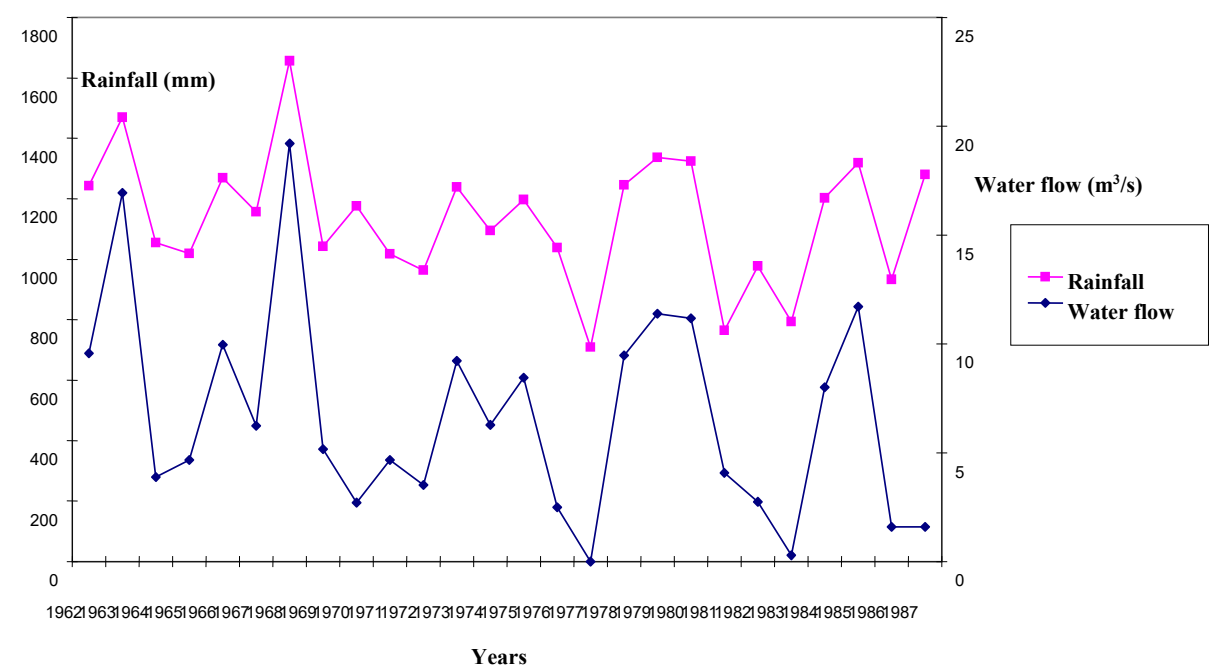

Figure 12. Evolution of annual water flow and annual average rainfall over the catchment: Haho at Gati

(1962-1987)

\subsubsection{Mono Regime}

Mono is a scanty and very irregular stream. It is known for long periods of low water with complete drying. The average monthly flow observed from February to April (low water level) is $0 \mathrm{~m} 3 / \mathrm{s}$ (completely dry), while that of September, the main month of flood is $261 \mathrm{~m} 3 / \mathrm{s}$, which shows of its very great seasonal irregularity. The Mono has its source near Alédjo-Koura, around $9^{\circ} 30 \mathrm{~N}$, so far beyond the northern limits of the Maritime Zone; it has a typical tropical diet; it is first fed by the waters of its source, but most of the diet depends on the almost Sudanian character of the rains where the two maxima tend to melt into one; the Mono also benefits from the spread of the rains over a very extensive watershed in latitude. The regime ultimately depends on the first rainy season (March, June) and the flood, corresponding to rainfall in the northern part of the watershed, concentrated 
between July October, the waters of this rainfall, crossing impervious granite gneissic terrains of the Precambrian basement, descending in half on the sea, sedimentary area, causing rapid floods.

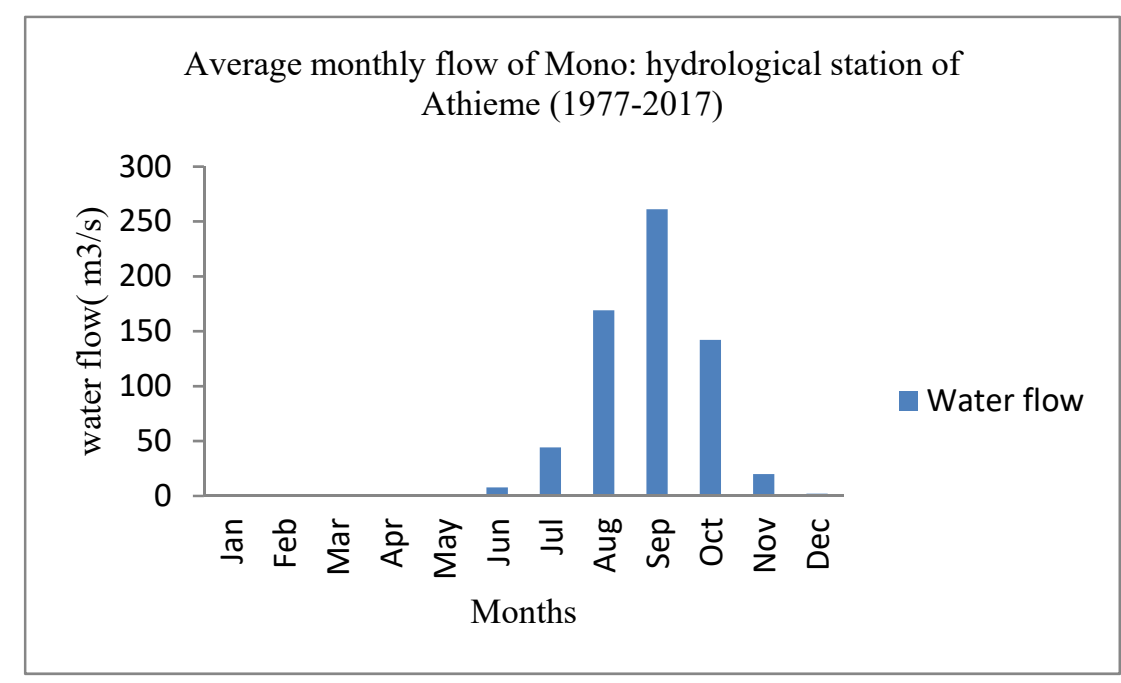

Figure 13. Average monthly flow of Mono: Hydrological station of Athieme (1977-2017)

Flooding due to excessive rainfall in a short period of time is a frequent hazard in the flood plains of Mono River in Yoto District during monsoon.

\subsubsection{Groundwater Resources}

Like surface water, groundwater is unevenly distributed over time and space. Deep water resources are closely related to the nature of the subsoil. The groundwater level varies from one place to another. Recharge occurs directly from rainfall and surface water. The main operator of groundwater resources is the Togolese Water Company (TdE). Around $85 \%$ of total public national water supply in Togo comes from groundwater (Direction Generale de l'Eau et de l'Assainissement (DGEA, 2009). The main groundwater dependent cities are listed in the table below, along with the volume of groundwater abstracted per year by the Togolese Water Company (TdE) (DGEA, 2013). The main groundwater dependent industries are the phosphates industry with an estimated groundwater abstraction of 4million cubic meters per year and the brewing industry with an estimated groundwater abstraction of 0.35 million cubic meters per year. The amount of groundwater removed by aquifer, both by the TdE and through private boreholes is given in the table 3 (Ministry of Water, sanitation and village hydraulics (MEAHV) / Direction Generale de l'Eau et de l'Assainissement (DGEA, 2013).

Table 2. The main groundwater dependent cities

\begin{tabular}{llll}
\hline City in Maritime region & Volume of groundwater abstracted $\left(\mathrm{m}^{3} / \mathrm{yr}\right)$ & City in other regions & Volume of groundwater abstracted $\left(\mathrm{m}^{3} / \mathrm{yr}\right)$ \\
\hline Lome & $13,873,129$ & Bassar & 207,636 \\
Tabligbo & 893,454 & Tchamba & 111,290 \\
Tsevie & 656,564 & Kante & 106,037 \\
Aneho & 160.541 & Sotouboua & 63,648 \\
Vogan & 100,310 & Guerin Kouka & 54,106 \\
\hline
\end{tabular}

Table 3. The amount of groundwater removed by aquifer

\begin{tabular}{lllll}
\hline Aquifer & $\begin{array}{l}\text { Volume abstracted by } \\
\mathrm{TdE}\left(\mathrm{M} \mathrm{m}^{3} / \mathrm{yr}\right)\end{array}$ & $\begin{array}{l}\text { Volume abstracted by } \\
\text { industry and private } \\
\text { boreholes }\left(\mathrm{M} \mathrm{m}^{3} / \mathrm{yr}\right)\end{array}$ & $\begin{array}{l}\text { Volume abstracted } \\
\text { rurally }\left(\mathrm{M} \mathrm{m}^{3} / \mathrm{yr}\right)\end{array}$ & Total $\left(\mathrm{M} \mathrm{m} \mathrm{m}^{3} / \mathrm{yr}\right)$ \\
\hline Continental Terminal & 10.6 & 4.3 & 1.7 & 1.0 \\
Paleocene Limestone & 3.3 & 4.7 & 0.4 & 9 \\
Maestrichtian & 4.2 & 2.0 & - & 6.6 \\
Basement Aquifers & 0.22 & - & - & - \\
Volta Basin & 0.26 & - & & - \\
\hline
\end{tabular}


The continental Terminal Aquifer is overexploited for drinking water and industrial use in Maritime region and is affected by sea water intrusion. Groundwater in coastal area especially Lomé was found to be very saline ( $\mathrm{NaCl}$ water type) and highly polluted with nitrate (Alfa-Sika, Tchakala, Chen, Boundjou, \& Bawa, 2017).

\section{Conclusion}

Global warming is already underway with consequences that must be faced today as well as tomorrow. Maritime region of Togo shows a local signature of this phenomenon as the mean temperature of the region rose by 2.2 degree Celsius at Lomé and 1.7 degree Celsius at Tabligbo. The results of the analysis of climate data for a long enough period (30 to 50 years) demonstrated a change on rain distribution after 1960 which is prejudicial to rainfall agriculture practiced by about $90 \%$ of Togolese crop growers. Natural disasters such as floods, droughts, and the scarcity of fresh water due to the intrusion of saline water are some of the consequences of global warming. Local populations need to be informed of current and future environmental changes in order to make adequate preparations and relevant adjustments since most of the environmental changes in Africa are related to rainfall (which is very crucial for the livelihood of the people). We are aware that the vulnerability of water resources due to global warming is at the root of many serious socioeconomic crises around the world. Among these we will mention the decline in food production resulting in famine, the energy crisis resulting in a slowdown in economic activities and especially the appearance of many diseases related to the scarcity of water.

Reducing greenhouse gas emissions has never been the top priority for a continent whose few industries produce only small amounts of greenhouse gases. As a matter of fact, sustainable adaptation strategies, better preparation of cities to cope with floods and disease outbreaks through urban and health planning research, conservation of water to reduce their vulnerability to drought, improve agricultural production and food distribution to ensure a more stable food supply to better withstand extreme weather events are the challenges for African countries. Meeting theses adaptation challenges is the responsibility not only for the African nations that are facing them but also of the developed countries that have historical responsibility for most global warming emissions.

\section{References}

Adewi, E., Badameli, K., \& Dubreuil, V. (2010). Evolution of Seasonal Potentially Useful Rains in Togo from 1950 to 2000. Climatologie, 77, 89-107.

Adoussi, P., \& Edjame, K. (2000). Changement Climatique Global: Evaluation de L'évolutaion des Parameters Climatiques. Lomé: Université de Lomé .

Alfa-Sika, M., Tchakala, I., Chen, H., Boundjou, G., \& Bawa, L. (2017). Sika Mande.SLA, TchakalaI, Chen H, et al. Hydrochemical Control of Groundwater Quality in an Urban Area of Lome Aquifer, Togo. International Journal of Chemical Sciences, 15 (4), 1-8.

Badameli, K. (1998). Analysis and Taking Account of Climate Risks in Agriculture; Case of the Maritime Region of Togo. Travaux et Recherché Geographiques, 239-250.

Badameli, K. (1996). La variabilité Climatique et la Production Agricole au Togo, Climate Variability and Agricultural Production in Togo. Bordeaux: University of Bordeaux III.

Collins, W., Bellouin, N., Doutriaux-Boucher, M., Gedney, N., Halloran, P., Hin-ton, T., et al. (2011). Development and Evaluation of an Earth-System Mode-HadGEM2. Geoscientific Model Development, 44, 1051-1075.

Defrance, D., Ramstein, G., Charbit, S., Vrac, M., Famien, A., Sultan, B., et al. (2017). Consequences of rapid ice sheet melting on the Sahelian population vulnerability. PNAS, 1-6.

DGEA. (2013). Africa groundwater atlas, Hydrogeology by country, Hydrology of Togo. DGEA.

DGEA. (2009). Rapport de synthèse: Gestion intégrée des ressources en eau (GIRE) ey objectif du Millénaire pour le Développement. New York: UNDESA.

Djaman, K., \& Ganyo, K. (2015). Trend Analysis in Reference Evapotranspirationand Aridity Index in the Context of Climate Change in Togo. Journal of Water and Climate Change, 55, 848-864.

Food and Agriculture Organization of the United Nations (FAO). (2017). Africa Regional Overview of Food Security and Nutrition. Accra: FAO.

Gadédjisso, T. (2015). Understanding Farmers' Perceptions of and Adaptations to Climate Change and Variability: The Case of the Maritime Plateau and Savannah Regions of Togo. Agricultural Sciences, 66, 1441-1454. 
Global Facility for Disaster Reduction and Recovery (GFDRR). (2011). Climate Risk and Adaptation Country Profile; Management Programs for Priority Countries: Togo case study. Lome: GFDRR.

Hubert, P., Carbonnel, J. P., \& Chaouche, A. (1989). Segmentation des Series Hydrometeorologiques: Application a Des Series de Precipitations et de Debits del'Afrique de L'Ouest. Journal of Hydrology, 110 (3-4), 349-367.

Hubert, P., Servate, E., Paturel, J., Kouame, B., Bendjoudi, H., Carbonnel, J., et al. (1998). La procédure de segmentation, dix ans après. IAHS Publication, 267-273.

Intergovernmental Oceanographic Commission (IOC). (2010). Existing and needed African Science-base for Coastal Adaptation. UNESCO, IOC. Paris: UNESCO.

Intergovernmental Panel on Climate Change (IPCC). (2013). Climate Change: The Physical Science Basis. In T. Stocker, D. Qin, G.-K. Plattner, M. Tignor, S. Allen, J. Boschung, et al., Contribution of Working Group I to the Fifth Assessment Report of the Intergovernmental Panel on Climate Change (p. 1535). Cambridge: Cambridge University Press.

Jalloh, A., Nelson, G. C., Thomas, T. S., Zougmore, R., \& Roy-Macauley, H. (2013). West African Agriculture and Climate Change: A comprehensive Analysis. Washington, DC: International Food Policy Research Institute (IFPRI).

Klassou, K. (1996). Recent Climatic and Hydrological Evolution and Impact on the Environment: The Case of the Mono River Watershed (Togo-Benin). Bordeaux: University Michel de Montaigne Bordeaux .

Kodjovi, E. S. (2011). Le rechauffement climatique: Gestion de l'eau et de l'environnement au Togo. Ouagadougou.

Lamb, P. J. (1982). Persistence of Sub-Saharan drought. Nature, 299, 46-48.

National Institute of Statistics and Economic and Demographic Studies (INSEED-TOGO). (2015). Perspective demographique du Togo 2011-2031. Lome: INSEED-TOGO.

Nicholson, S. (2011). Climatic and Environmental Change in Africa during the Last Two Centuries. Climate Research . 17, 123-144.

Nicholson, S. E. (1988). Atlas of African Rainfall and its Interannual Variability. Tallahassee: Department of Meteorology, Florida State University.

Odjugo, P. (2010). General Overview of Climate Change Impacts in Nigeria. Journal of Human Ecology, 29, 47-55.

Oguntunde, P., Abiodun, B., \& Gunnar, L. (2012). Spatial and Temporal Temperature Trends in Nigeria, 1901-2000. Meteorology and Atmospheric Physics, 95-105.

Ozer, P., Hountondji, Y.-C., Niang, A. J., Karimoune, S., Manzo, O. L., \& Salmon, M. (2010). Désertification au Sahel : historique et perspectives. Bulletin de la Société Géographique de Liège, 54, 69-84.

Paturel, J., Servat, E., Kouamé, B., Lubès, H., Ouedraogo, M., \& Masson, J. (1997). Climatic variability in humid Africa along the Gulf of Guinea Part II: an integrated regional approach. Journal of hydrology, 16-36.

Sodogas, A., \& Gomado, K. (2006). Analyse situationnelle des risques et facteurs de risques potentiels en matière de désastres au Togo.

Sogbedji, J. (1999). Maize Nitrogen Utilization and Nitrate Leaching Modeling in Togo and New York. New York: Cornell University.

Stringer, L. C., Akhtar, M., Marques, M. J., Amiraslami, F., Quatrini, S., \& Abraham, E. M. (2011). Combating Land Degradation and Desertification and Enhancing Food security: Towards Integrated Solutions. Anals of Arid Zone, 1-23.

UNFCCC. (2018). Climate Change. Cooco, 4 (3), 32-45.

United Nations Development Programme (UNDP) \& Ministère de l'Environnement et des Ressources Forestières Togo. (2009). Plan d'Action National d'Adaptation aux Changements Climatiques Togo-PANA. New York: UNDP.

United Nations Framework Convention on Climate Change (UNFCCC). (2011). Fact Sheet: Climate Change Science-The Status of Climate Change Science Today. New York: UNFCCC. 
Vyve, N. V. (2006). Caractérisation de la variabilité spatio-temporelle. UNIVERSITE CATHOLIQUE DE LOUVAIN, Faculté d'ingénierie biologique, agronomique et environnementale. Louvain-la-Neuve : UNIVERSITE CATHOLIQUE DE LOUVAIN .

Wade, S., Faye, S., Dieng, M., Kaba, M., \& Kane, N. (2009). Télédétection des catastrophes d'inondation urbaine: Le cas de la région de Dakar. Journal d'Animation Scientifique, 1-7.

Zheng, X., Reid, E., \& Craing, S. (1997). Trend Detection in Regional-Mean Temperature Series: Maximum Minimum Mean Diurnal Range and SST. Journal of Climate, 10, 317-326.

\section{Copyrights}

Copyright for this article is retained by the author(s), with first publication rights granted to the journal.

This is an open-access article distributed under the terms and conditions of the Creative Commons Attribution license (http://creativecommons.org/licenses/by/4.0/). 